\title{
Transcriptional Enhancer Factor TEF-3
}

National Cancer Institute

\section{Source}

National Cancer Institute. Transcriptional Enhancer Factor TEF-3. NCI Thesaurus. Code C158840.

Transcriptional enhancer factor TEF-3 (434 aa, $48 \mathrm{kDa}$ ) is encoded by the human

TEAD4 gene. This protein plays a role in transcriptional regulation in the hippo signaling pathway. 